\title{
Pemanfaatan Media Sosial Twitter Oleh Ridwan Kamil Dan Ganjar Pranowo Telah Sesuai Dengan Fungsi Utama Media Massa
}

\author{
Andrea Eka Premasadha Harrera \\ (mckeliling@gmail.com) \\ (Magister Ilmu Komunikasi FISIP Universitas Diponegoro)
}

\begin{abstract}
The development of social media makes a lot of people should follow it. We are required to be able to use social media as a medium that can simplify our lives, as we can find a lot of information or news through the media. On the other hand, social media can also facilitate the work of someone. In this research, the researcher want to see that social media twitter belonging to Ridwan Kamil and Ganjar Pranowo which they use as a medium to get closer to the citizens, in accordance with the essential function of the mass media. This research using qualitative research method with observation the timeline twitter of @ridwankamil and @ganjarpranowo. Then, from the observation, It is indicate that the twitter account has complied with all the essential functions of a mass media
\end{abstract}

Keywords: Sosial Media, Ridwan Kamil, Ganjar Pranowo

\section{Pendahuluan}

Perkembangan media memang seperti tidak bisa lagi dipisahkan oleh kehidupan seseorang saat ini. Seakan akan media "memaksa" kita untuk menggunakannya demi kelangsungan hidup kita. Dalam artian di era modern saat ini kita dituntut untuk tau segala hal, dan dengan menggunakan media inilah kita bisa membuat diri kita tau banyak hal, mulai dari masalah politik, ekonomi, sosial, bahkan masalah rumah tangga seseorang kita bisa mengetahuinya melalui sebuah media. Saat ini media konvensional seperti koran ataupun radio bukanlah menjadi unggulan lagi bagi seseorang yang ingin mendapatkan berita terbaru. Hadirnya media baru saat ini seakan membuat pamor dari koran dan radio menjadi tergeserkan. Sebut saja twitter, sebuah media baru berjenis micrblogging yang bisa memberikan kita kemudahan untuk mendapatkan berita secara cepat dan singkat saat ini. Seseorang akan merasa tercukupi kebutuhan akan rasa keingin tahuannya dengan menggunakan media microblogging twitter ini.
Microblog sendiri adalah bentuk blog yang membatasi ukuran setiap postnya. Sebagai salah satu media sosial penyedia layanan microblog, maka twitter memberikan fasilitas penulisan pesan yang hanya dapat menampung $\quad 140 \quad$ karakter (Zarrella,2010:31).

Kehebatan twitter inilah yang tidak jarang di manfaatkan oleh beberapa orang untuk memudahkan melakukan pekerjaannya, sebagai contoh seorang kepala daerah yang menggunkan twitter sebagai media untuk mendengarkan keluhan keluhan dan masukan dari warganya, demi kemajuan daerah tersebut. Dan di Indonesia sendiri hal tersebut sudah dilakukan oleh beberapa kepala daerah yang memang aktif sekali "bermain" media mikro blogging twitter ini.

Sebut saja walikota Bandung, bapak Ridwan Kamil yang sampai saat ini telah memiliki 1,2 juta pengikut atau followers di akun twitter miliknya yaitu@ridwankamil. Hal tersebut ia manfaatkan dengan sangat baik, untuk menjaga "kedekatan" dengan warganya yang menggunakan situs 
mikro blogging twitter. Tidak hanya Ridwan Kamil saja yang memanfaatkan twitter sebagai media untuk membangun daerahnya menjadi lebih baik lagi,karena gubernur Jawa Tengah, bapak Ganjar Pranowo pun sangat aktif menggunakan akun twitter pribadinya untuk mendengarkan dan menanggapi masukan serta kritikan dari warga Jawa Tengah sendiri khususnya. Beliau hingga saat ini mempunyai pengikut atau followers di akun twitternya yaitu @ganjarpranowo sebesar 540 ribu pengguna.

Bukan sebuah angka yang kecil bagi pengguna jejaring sosial twitter saat ini, dan hal ini membuktikan bahwa masyarakat mulai bisa menerima kehadiran media twitter bukan hanya sebagai media sosial yang bisa menghubungkan kita dengan seseorang, melainkan sebuah media sosial yang juga dapat membantu atau mempermudah pekerjaan seseorang. Dalam penelitian ini, peneliti ingin melihat apakah penggunaan media sosial twitter oleh walikota Bandung dan gubernur Jawa Tengah ini telah sesuai dengan fungsi media massa di Indonesia?.

Situs jejaring sosial atau media sosial awalnya muncul berdasarkan sebuah ide atau pikiran untuk mengumpulkan orang - orang dari seluruh belahan dunia. Media sosial sendiri adalah sebuah teknologi yang digunakan secara efektif untuk berkomunikasi dengan orang lain, membangun hubungan, dan membangun kepercayaan (Safko, 2010). Sesuai dengan karakteristik media sosial menurut Mayfield (2008) yaitu memungkinkan penggunanya untuk berbagi informasi dan berinteraksi, maka pada tahun 1997, merupakan awal kemunculan situs jejaring sosial yang pertama yaitu Sixdegrees.com , lalu disusul pada tahuun 1999 dan 2000 muncul situs jejaring sosial lainnya seperti, lunarstorm, live journal, dan cyword.

Barulah pada tahun 2010, Friendster sebuah situs jejaring sosial yang sangat fenomenal selama beberapa tahun muncul. Sistem kerja Friendster sendiri mirip dengan sistem "Multi Level Marketing" (MLM). Dengan kata lain, jika kita punya teman di Friendster, secara langsung kita akan masuk dalam jaringan teman kita tersebut. Yang bisa dibilang unik dari Friendster adalah, selain dapatmendiskripsikan diri lewat identitas dan foto, situs jejaring sosial ini juga menyertakan testimonial yang diharapkan dapat menggambarkan si pemilik akun dengan lebih obyektif.

Namun keberadaan situs yang merupakan pelopor situs jejaring sosial tersebut harus berakhir pada tahun 2007, ketika sebuah jejaring sosial bernama Facebook hadir ditengah - tengah masyarakat. Pengguna Friendster berdalih bahwa situs jejaring sosial Facebook lebih mudah digunakan dan mempunyai banyak kelebihan yang tidak dimiliki oleh Friendster. Praktis sejak saat itu pengguna mereka berkurang yang berpengaruh pada pendapatan friendster, sehingga friendster mengalami kebangkrutan.

Kemudian sejalan dengan prkembangan facebook yang luar biasa cepat, muncul lah sebuah jejaring sosial berjenis micro blogging, yaitu sebuah jejaring sosial yang hanya dapat menuliskan kata - kata tidak lebih dari 140 karakter, yang bernama Twitter. 
Kisah perjalanan situs jejaring sosial mikro blogging Twitter ini berawal pada bulan Maret 2006 bersama dengan 3 orang pendirinya yaitu Jack Dorsey, Evan Williams dan Biz Stone. Mereka bertiga berasal dari latar belakang pekerjaan yang berbeda,Evan Williams dan Biz Stone yang berasal dari Google, Kemudian Jack Dorsey yang merupakan karyawan Odeo.

Kemudian pada akhir 2006, Evan Williams bersama dengan Biz Stone mendirikan sebuah perusahaan, yaitu Obvious Corp dengan mantan karyawan Odeo.Awal berdirinya Twitter dimulai dari sebuah perusahaan yang terpisah pada April 2007 dari Obvious Corp.

Posisi Jack Dorsey sendiri adalah chief executive officer sampai Oktober 2008, namun ketika Evan Williams menjadi CEO, Jack Dorsey bergeser ke posisi ketua dewan direksi. Jack Dorsey merupakan pencetus ide twitter dalam sebuah diskusi yang diselenggarakan oleh podcasting perusahaan Odeo.

Ia memiliki suatu ide mengenai sebuah pesan atau 'status', seperti pengiriman pesan atau status mengenai apa yang sedang seseorang lakukkan, kemudian dengan siapa dia berinteraksi, hingga pada akhirnya akan membentuk sebuah interaksi percakapan antar pengguna.Konsep awal dari twitter adalah sebuah sistem dimana pengguna dapat mengirimkan pesan yang dengan cepat menyebar ke pengguna yang lain yang berteman dengannya. Namun, dengan melakukkan diskusi dan koreksi serta pertimbangan - pertimbangan lainnya, maka saat ini twitter telah berkembang menjadi sebuah layanan jejaring sosial yang memiliki fitur untuk menerbitkan posting singkat, atau status yang mirip dengan SMS namun dapatdiakses menggunakan Internet.

Pada tanggal 15 Juli 2006 dimulailah proyek pembuatan twitter secara terbuka. Kemudian pada bulan April 2007twittersecara resmi menjadi sebuah perusahaan, dengan nama Twitter,Inc. Kepopuleran twitter mulai dirasakan, ketika pada tahun 2007 bertepatan dengan diadakannya festival musik yang cukup populer South by Southwest (SXSW). Selama acara tersebut penggunaan twitter meningkat sebanyak 40.000 tweets per hari, dari 20.000 tweets per hari menjadi 60.000 tweets per hari.

Dari situlah orang - orang mulai mencoba menggunakan situs mikro blogging 140 karakter ini. Walaupun hanya dibatasi dengan 140 karakter, bukan berarti twitter tidak dapat bersaing dengan facebook. Justru keunikan 140 karakter itulah yang membuat pengguna jatuh hati dengan twitter. Sementara itu, berdasarkan Kusuma (2009:11 \& 17) terdapat beberapa istilah - istilah yang umum ditemui pada Twitter, yaitu:

a. Timeline adalah daftar tweet terbaru dari pengguna twitter yang diikuti pemilik akun, termasuk tweet yang dibuat pemilik akun.

b. Direct Message (DM) yaitu fasilitas berkirim pesan antar pengguna secara lebih private. DM hanya bisa dilakukan oleh pihak yang diikuti (di-follow).

c. Trending topics adalah daftar tema

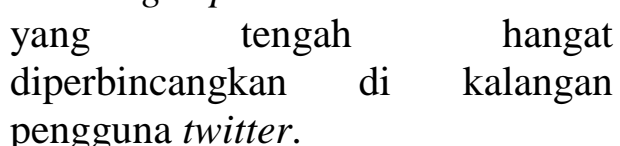

d. Tweet merupakan informasi yang terdiri dari pesan 140 karakter. Tweet berisi berita terbaru ("apa yang sedang terjadi") yang berkaitan dengan hal - hal yang pemilik akun sukai. 
e. Reply tweet atau response tweet (RT) adalah komentar atau balasan atas

tweet.

f. Retweet adalah menyalin seluruh isi tweet dari akun lain.

g. Follow adalah mengikuti akun dan informasi yang disampaikan oleh seorang pengguna.

h. Follower adalah pengikut atau yang mengikuti akun seseorang.

i. Mention (@) digunakan untuk menyebut username pihak yang akan diajak berkomunikasi. Penggunaan simbol ini berada di awal sebelum menuliskan username pihak yang dituju.

j. Hastags atau tanda pagar atau tagar (\#) adalah tanda yang digunakan untuk menandai kata kunci untuk topik diskusi atau informasi yang dibagikan agar mudah dicari.

Pengguna twitter yang terus bertambah tidak terlepas dari perkembangan tekhnologi saat ini, sebagai contohnya adalah perkembangan handphone, yang semula hanya berfungsi sebagai alat untuk melakukan komunikasi via telpon atau sms, saat ini berkembang menjadi sebuah alat komunikasi yang bisa menghubungkan orang dari seluruh dunia hanya menggunakan jaringan internet saja.

Handphone berlabel smartphone inilah menjadi salah satu faktor semakin bertambahnya jumlah pengguna media sosial khusus nya twitter ini. Berikut adalah sebuah diagram yang diambil dari sebuah situs bernama www.statista.com yang menunjukan perkembangan situs mikro blogging twitter hingga pertengahan tahun 2015.

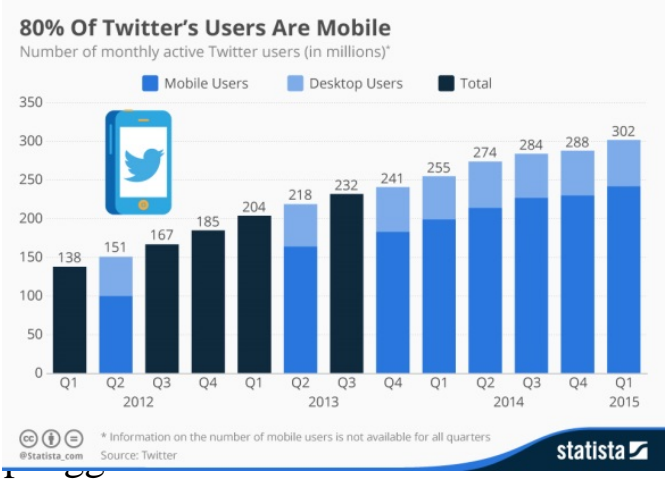

diseluruh dunia, yang mengakses situs mikro blogging tersebut menggunakan handphone atau smart phone cenderung mengalami peningkatan di setiap tahunnya. Hal ini membuktikan bagaimana media sosial sangat erat hubungannya dengan perkembangan tekhnologi saat ini.

Di Indonesia sendiri pertumbuhan pengguna twitter sangatlah cepat, hal ini dikarenakan hingga tahun 2015, pengguna aktif internet di Indonesia sudah mencapai angka 72,7 juta pengguna, dimana 72 juta penggunanya sendiri merupakan seseorang yang aktif menggunakan media sosial. Dan berikut adalah info grafis pengguna internet di Indonesia, yang dibuat oleh suatu agensi marketing sosial yang bernama We Are Social :

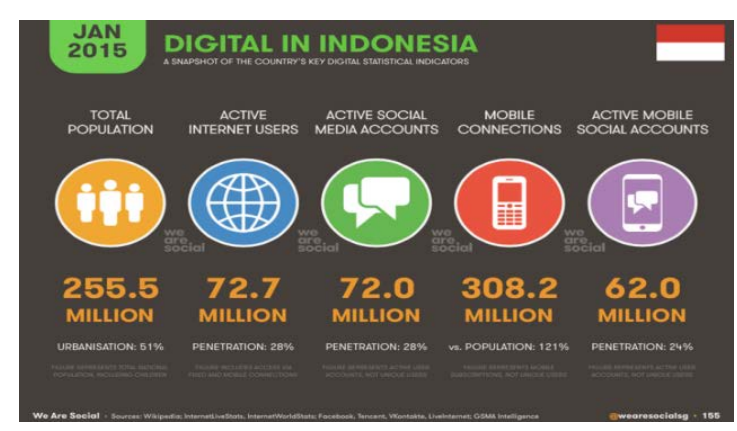

Gambar 2. Perkembangan pengguna internet di Indonesia

Dari gambar tersebut dapat terlihat bahwa negara Indonesia merupakan 
satu kawasan yang sangat potensial bagi pelaku bisnis yang bergerak dibidang tekhnologi komunikasi, seperti facebook, twitter, whatsapp, line, dan lain sebagainya.

Tidak hanya itu saja, agensi We Are Social ini juga memberikan hasil pengolahan data mereka mengenai "platform" sosial media apa saja yang sejauh ini berhasil menguasai pasar dalam negeri :



Gambar 3. Perkembangan platfrom media sosial di Indonesia

Berdasarkan gambar tersebut dapat kita lihat bahwa jenis platform media sosial terbagi menjadi dua jenis, yaitu "Social Network" dan "Mesenger / Chat App / VOIP”. Untuk kategori "Social Network" sendiri masih terbanyak dikuasai oleh facebook, kemudian disusul oleh platform mikro blogging twitter, dan google + . Sementara itu untuk kategori "Mesenger / Chat App / VOIP" dikuasai oleh platform whatsapp, facebook messanger, dan skype. Meskipun dari data tersebut posisi twitter masih kalah dengan posisi facebook, bukan berarti popularitas twitter di Indonesia tidak baik.

Banyak hal yang dapat membuktikan bahwa twitter juga sebuah platform yang diakui dunia sebagai salah satu pengguna tebanyak di dunia. Bahkan beberapa orang di Indonesia mempunyai pengikut atau followers yang berjumlah jutaan, dan membuat akun tersebut mendapatkan "verified" oleh pihak twitter.inc itu sendiri, sebut saja Raditya Dika, seorang arti, comedian, sineas muda Indonesia yang mempunyai followers mencapai 12,8 juta orang, dan menjadikan akun miliknya di akui atau ter "verified" langsung oleh pihak twitter dengan munculnya tanda "centang biru" disebelah nama profile pengguna.

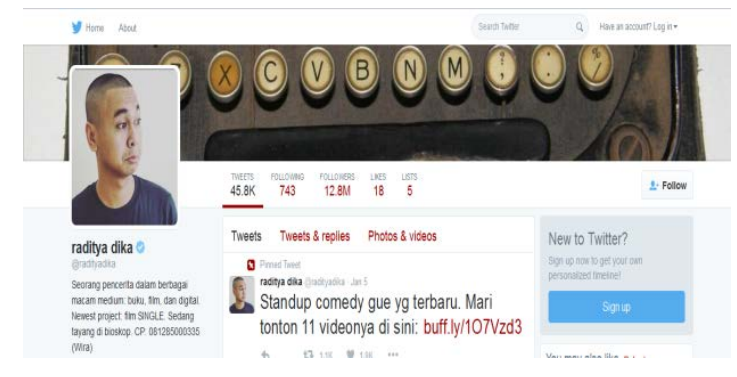

Gambar 4. Twitter @radityadika

Media sosial mikro blogging twitter tidak hanya merambah ke selebriti selebriti di Indonesia saja, melainkan juga masuk kedalam ranah politik. Terbukti banyak sekali pelaku politik yang sudah mulai menggunakan media sosial twitter ini. Tidak jarang juga mereka yang dapat melihat "celah" dari sebuah akun twitter yang mereka punya, dapat memanfaatkannya sebagai sarana untuk mempermudah pekerjaan mereka.

Ada dua sosok kepala daerah yang sangat aktif menggunakan media sosial twitter miliknya, yaitu Ridwan Kamil, seorang walikota Bandung, Jawa Barat, serta seorang gubernur Jawa Tengah yaitu Ganjar Pranowo.

\section{Pembahasan}

Menurut Sholihati (2007:35), secara teoritis ideologis, media massa di Indonesia memiliki 5 fungsi utama:

\section{Fungsi Informasi}

Fungsi ini merupakan fungsi utama komunikasi secara umum dan merupakan unsur yang sudah 
terpenuhi secara mutlak oleh media massa. Informasi dibutuhkan oleh khalayak, karena mereka membutuhkan informasi mengenai peristiwa yang terjadi, gagasan, atau fikiran orang lain, apa yang dilakukan oranglain , dan sebagainya.

\section{Fungsi Mendidik}

Media massa dapat menjadi sarana pendidikan massa, dalam upaya memenuhi kebutuhan masyarakat di bidang pembelajaran, media massa menyajikan beberapa peristiwa tentang proses - proses sosial, politik, dan budaya yang secara kognitif memberikan wawasan yang lebih luas kepada masyarakat.

\section{Fungsi Hiburan}

Fungsi hiburan dalam tatanan ideal merupakan salah satu tuntutan yang harus dipenuhi media massa, sudah dijalankan secara optimal. Dengan melihat perilaku media massa nampaknya menjadikan fungsi hiburan ini menjadi target yang paling penting harus dipenuhi.

\section{Fungsi Persuasi}

Fungsi persuasi ini ada peran yang dijalankan oleh suatu media massa untuk mempengaruhi dan merubah pola hidup masyarakat melalui pesan - pesan yang disampaikan. Hal ini menjadikan fungsi persuasi pada media massa memegang peranan penting dalam kehidupan masyarakat.

\section{Fungsi Kontrol Sosial}

Pola kehidupan sosial masyarakat saat ini sedang mengalami pergeseran nilai yang cukup signifikan. Perubahan pada pola fikir, sikap, dan persepsi terhadap lingkungan, serta pola perilaku memiliki kecenderungan pada semakin menguatnya paradigma pragmatisme yang serba instan. Oleh sebab itu media harus bisa mengontrol lingkungan sosial dalam masyarakat.

Dan berikut ini, hasil penelitian kepada akun twitter @ridwankamil selaku walikota Bandung dan @ganjarpranowo selaku gubernur Jawa Tengah.

\section{Ridwan Kamil (@ridwankamil) Walikota Bandung, Jawa Barat}

\section{Fungsi Informasi}

ridwan kamil @idwankamil Jan 21 punya usaha, produk \& merk sendiri, segera daftarkan ke Dinas KUKM \& Perindag Kota Bdg. Gratis.

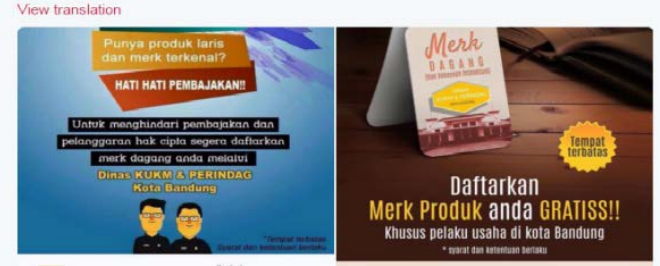

Gambar 5. Akun @ridwankamil memberikan informasi kepada warganya

Gambar tersebut menjelaskan bahwa akun@ridwankamil memberikan informasi kepada warganya yang mempunyai usaha atau produk untuk di daftarkan ke Dinas KUKM \& Perindag kota Bandung.

\section{Fungsi Mendidik}

Dalam waktu dekat dlm rangka MEA, berbisnis menengah mikro di BDG tidak usah pake ijin, cukup pemberitahuan. Smg ini mengakselerasi ekonomi.



Gambar 6. Akun @ridwankamil memberikan wawasan seputar MEA kepada warganya

Gambar tersebut menunjukan akun @ridwankamil dapat memberikan fungsi mendidik kepada warganya 
melalui sebuah informasi yang menambah wawasan warganya yang menjadi pengikut atau followers akun twitternya. Di gambar tersebut terlihat akun@ridwankamil mencoba memberikan gambaran kepada warganya yang mempunyai bisnis menengah mikro terhadap kedatangan MEA atau Masyarakat Ekonomi ASEAN.

\section{Fungsi Hiburan}

Semoga tidak ada yang iseng menjadikan ini sebagai bahan batu akik. amin.

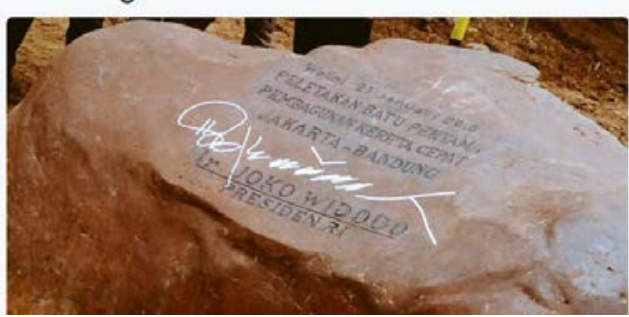

Gambar 7. Akun @ridwankamil memposting foto dengan caption yang lucu

Gambar tersebut menunjukan bahwa @ridwankamil memberikan "caption” atau kata - kata yang menggelitik (jenaka) untuk sebuah foto peletakan batu pertama pembangunan kereta cepat Jakarta - Bandung.

\section{Fungsi Persuasi}

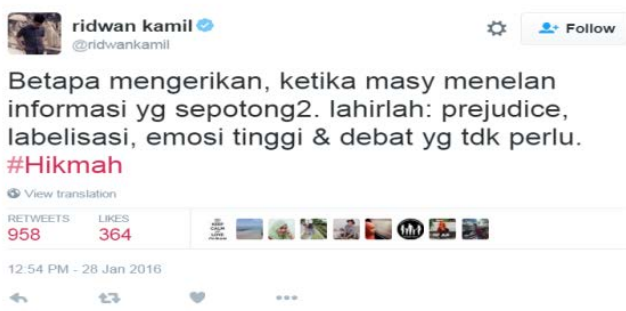

Gambar 8. Akun @ridwankamil melakukan fungsi persuasi sebagai media massa

Gambar tersebut menjelaskan bahwa akun@ridwankamil menocba memaparkan pendapat pribadinya yang kemudian diharapkan juga dapat merubah pandangan masyarakat, khususnya "followers" akun @ridwankamil terhadap apa yang ia rasakan.

\section{Fungsi Kontrol Sosial}

ridwan kamil 2. Follow

Warga Bdg, ini prog Microlibrary di Taman2 kota ut menaikan budaya literasi/baca. ini di Tmn Lansia. *Design by SHAU

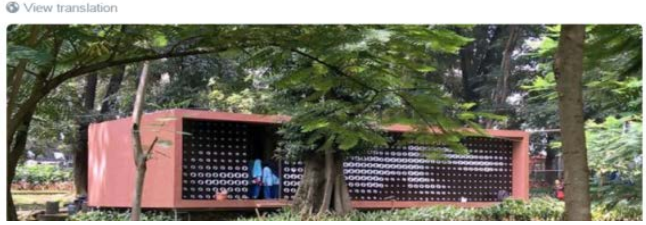

Gambar 9. Akun @ridwankamil memberikan foto tentang program Microlibrary

Gambar tersebut menunjukan bahwa akun@ridwankamil memberikan informasi tentang program "Microlibrary" kepada warga kota Bandung yang menjadi "followers" nya untuk menaikan budaya membaca dengan adanya "Microlibrary" tersebut.

Ganjar

Pranowo

(@ganjarpranowo), Gubernur Jawa Tengah.

\section{Fungsi Informasi}



Gambar10.Akun@ganjarpranowo informasi tentang virus Zika (DBD)

Gambar tersebut menunjukan bahwa akun@ganjarpranowo memberikan informasi tentang virus Zika (DBD) kepada pengikutnya atau followersnya agar lebih bisa waspada dan lebih bisa 
menjaga lingkungannya masing masing.

\section{Fungsi Mendidik}

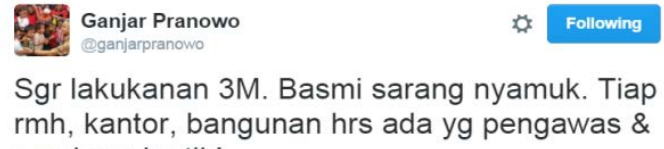

Sgr lakukanan 3M. Basmi sarang nyamuk. Tiap rmh, kantor, bangunan hrs ada yg pengawas \& pemburu jentik!

supardi_su@gmail.com @su_supardi

@ganjarpranowo pk ganjar nyamuk dirumah rumah byk banget nih.mohon diadakan penyemprotan.matursumun pak

Gambar 11.Akun@ganjarpranowo meminta followersnya untuk melakukan $3 M$

Gambar tersebut menunjukkan bahwa akun@ganjarpranowo seperti mengingatkan kembali agar semua followersnya segera melakukan 3M di musim penghujan, dimana seperti yang diketahui wabah penyakit yang disebabkan oleh nyamuk mulai bermunculan.

\section{Fungsi Hiburan}

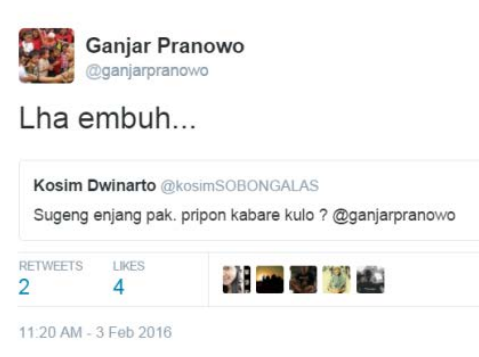

Gambar 12. Akun@ganjarpranowo menjawab pertanyaan dengan ciri khas orang jawa

Gambar tersebut menunjukan akun @ganjarpranowo mencoba menjawab pertanyaan yang terlihat tidak terlalu jelas maksut dari pertanyaan itu sendiri, dengan menggunakan bahasa jawa yang santai, seperti melucu. Jawaban dari akn @ganjarpranowo tersebut dapat memicu tawa dari followersnya apabila membacanya.

\section{Fungsi Persuasi}

Anak2 ini perlu kita bantu agar masa depannya lbh baik

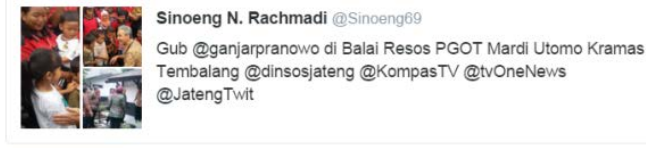

Gambar 13. Akun @ganjarpranowo membuat ajakan untuk semua followersnya

Gambar tersebut menjelaskan bahwa akun@ganjarpranowo melalui balasan twitter kepada akun @Sinoeng69 mengajak semua followersnya untuk ikut membantu adik - adik atau anak anak di PGOT Mardi Utomo Kramas Tembalang demi masa depan mereka yang lebih baik lagi. Hal ini dapat menjadi sesuatu yang sangat positif apabila semua bisa saling membantu satu sama lainnya.

\section{Fungsi Kontrol Sosial}
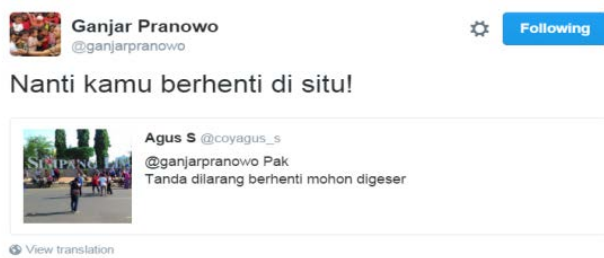

Gambar 14.Akun@ganjarpranowo memberikan penegasan terhadap pertanyaan followernya

Gambar tersebut menjelaskan bahwa akun@ganjarpranowo memberikan sebuah jawaban bernada tegas terhadap sebuah permintaan oleh followersnya dengan maksut untuk memberikan pengertian bahwa aturan yang telah ditetapkan punya tujuan yang baik bagi lingkungan atau daerah tersebut.

\section{Kesimpulan}

Kedua akun twitter @ridwankamil dan @ganjarpranowo sama - sama telah 
melakukan perannya sebagai sebuah media massa yang baik dan benar. Kedua akun tersebut dapat memberikan sebuah pelajaran yang penting bagi kita semua yang selama ini belum bisa memanfaatkan media sosial kita sebagai sebuah media massa yang baik dan benar. Besar harapan penliti, nantinya akan ada penelitian - penelitian lagi tentang hal yang serupa namun dengan objek yang berbeda, yang juga mempunyai pengaruh besar terhadap lingkungannya atau masyarakat luas.

\section{Daftar Pustaka}

Kurnia Widiastuti, Desi. (2014). Twitter Sebagai Media Alternatif Informasi Publik. Yogyakarta: Fishum.

Madcoms. (2011). Berinternet Dengan Facebook dan Twitter Untuk Pemula. Yogyakarta: Penerbit Andi.

McQuail, Denis. (1991). Teori Komunikasi Massa. Jakarta: Erlangga.

Safko, Lon. (2010). The Social Media Bible: Tactics, Tools, and Strategies for Business Success, Willey, New Jersey.

\section{Internet}

Twitter@@ridwankamil dalam https://twitter.com/ridwankamil ,diakses pada 28 Januari 2016 pukul 12:46 WIB

Twitter@ganjarpranowo dalam https://twitter.com/ganjarprano wo ,diakses pada 28 Januari 2016 pukul 14:30 WIB

https://etikajejaringsosial.wordpress.c om/about/pembahasan/sejarahdan-perkembangan-jejaringsosial/ , diakses pada 28 Januari 2016 pukul 11:45 WIB

https://akufredian.wordpress.com/201 1/01/02/sejarah-perkembangankebangkrutan-friendster/ diakses pada 28 Januari 2016 pukul 11:50 WIB

http://alamtekno.blogspot.co.id/2013/0 6/sejarah-twitter.html, diakses pada 28 Januari 2016 pukul 11:52 WIB

http://www.techno.id/social/bagaiman a-perkembangan-twitter-saatini-1509122.html, diakses pada 28 Januari 2016 pukul 11:57 WIB

http://www.statista.com/chart/1520/nu mber-of-monthly-active-twitter users/, diakses pada 28 Januari 2016 pukul 12:05 WIB

https://id.techinasia.com/laporan-30juta-pengguna-internet-diindonesia-adalahremaja/diakses pada 28 Januari 2016 pukul 12:15 WIB

https://id.techinasia.com/laporanpengguna-website-mobilemedia-sosial-indonesia/ diakses pada 28 Januari 2016 pukul 12:17 WIB 